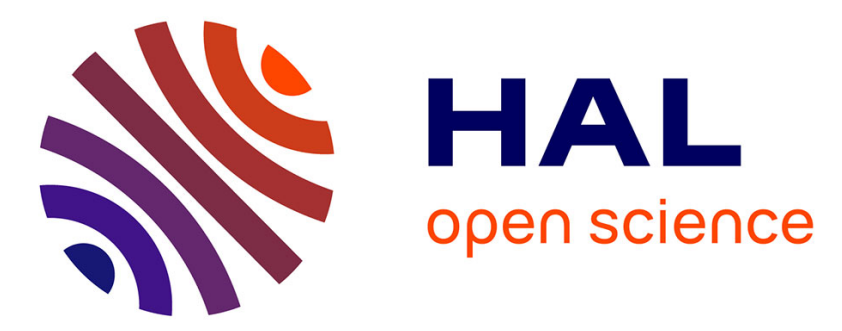

\title{
Wide range of metallic and organic contaminants in various tissues of the Antarctic prion, a planktonophagous seabird from the Southern Ocean
} Aymeric Fromant, Alice Carravieri, Paco Bustamante, Pierre Labadie, Hélène Budzinski, Laurent Peluhet, Carine Churlaud, Olivier Chastel, Yves Cherel

\section{To cite this version:}

Aymeric Fromant, Alice Carravieri, Paco Bustamante, Pierre Labadie, Hélène Budzinski, et al.. Wide range of metallic and organic contaminants in various tissues of the Antarctic prion, a planktonophagous seabird from the Southern Ocean. Science of the Total Environment, 2016, 544, pp.754764. 10.1016/j.scitotenv.2015.11.114 . hal-01260941

\section{HAL Id: hal-01260941 \\ https://hal.science/hal-01260941}

Submitted on 22 Jan 2016

HAL is a multi-disciplinary open access archive for the deposit and dissemination of scientific research documents, whether they are published or not. The documents may come from teaching and research institutions in France or abroad, or from public or private research centers.
L'archive ouverte pluridisciplinaire HAL, est destinée au dépôt et à la diffusion de documents scientifiques de niveau recherche, publiés ou non, émanant des établissements d'enseignement et de recherche français ou étrangers, des laboratoires publics ou privés. 
Wide range of metallic and organic contaminants in various tissues of the Antarctic prion, a planktonophagous seabird from the Southern Ocean

Aymeric Fromant ${ }^{\mathrm{a}}$, Alice Carravieri ${ }^{\mathrm{a}, \mathrm{b}, *}$, Paco Bustamante $^{\mathrm{b}}$, Pierre Labadie $^{\mathrm{c}}$, Hélène Budzinski $^{\mathrm{c}}$, Laurent Peluhet ${ }^{\mathrm{c}}$, Carine Churlaud ${ }^{\mathrm{b}}$, Olivier Chastel $^{\mathrm{a}}$, Yves Cherel $^{\mathrm{a}}$

${ }^{\mathrm{a} C e n t r e ~ d ' E t u d e s ~ B i o l o g i q u e s ~ d e ~ C h i z e ́, ~ U M R ~} 7372$ CNRS-Université de La Rochelle, 79360 Villiers-en-Bois, France

${ }^{\mathrm{b}}$ Littoral Environnement et Sociétés (LIENSS), UMR 7266 CNRS-Université de la Rochelle, 2 rue Olympe de Gouges, 17000 La Rochelle, France

'Université de Bordeaux, UMR 5805 EPOC (LPTC Research group), Université Bordeaux, 351 Cours de la Libération F 33405 Talence Cedex France

*Corresponding author: A. Carravieri.

E-mail address: carravieri@ cebc.cnrs.fr and alice.carravieri@gmail.com

\section{HIGHLIGHTS}

- Trace elements and POPs were measured in various tissues of 10 Antarctic prions

- Residue diversity was notable given the species' small size and low trophic position

- Cd, Se, BDE 183 and 209 showed noticeably high internal tissue concentrations

- Several POPs showed inter- and intra-tissues correlations, indicating co-exposure

- Blood was validated as a good bioindicator of internal tissue As and $\mathrm{Hg}$ levels 
ABSTRACT: Trace elements $(n=14)$ and persistent organic pollutants (POPs, $n=30$ )were measured in blood, liver, kidney, muscle and feathers of 10 Antarctic prions (Pachyptila desolata) from Kerguelen Islands, southern Indian Ocean, in order to assess their concentrations, tissue distribution, and inter-tissue and inter-contaminant relationships. Liver, kidney and feathers presented the highest burdens of arsenic, cadmium and mercury, respectively. Concentrations of cadmium, copper, iron, and zinc correlated in liver and muscle, suggesting that uptake and pathways of metabolism and storage were similar for these elements. The major POPs were 4,4'-DDE, mirex, PCB-153 and PCB-138. The concentrations and tissue distribution patterns of environmental contaminants were overall in accordance with previous results in other seabirds. Conversely, some Antarctic prions showed surprisingly high concentrations of BDE-209. This compound has been rarely observed in seabirds before, and its presence in Antarctic prions could be due to the species feeding habits or to the ingestion of plastic debris. Overall, the study shows that relatively lower trophic level seabirds (zooplankton-eaters) breeding in the remote southern Indian Ocean are exposed to a wide range of environmental contaminants, in particular cadmium, selenium and some emerging-POPs, which merits further toxicological investigations.

Keywords: Blood; Feathers; Metal; POPs; Procellariiformes; Trace elements 


\section{Introduction}

Trace elements and persistent organic pollutants (POPs) are commonly found in terrestrial and aquatic ecosystems worldwide (Walker et al., 2012). These environmental contaminants come from both natural and anthropogenic sources, and can exhibit toxic properties causing endocrine dysfunction, mutagenesis, or reproductive and behavioural disturbances (e.g., Scheuhammer, 1987; AMAP, 2004; Walker et al., 2012). Although polar marine environments are isolated from the major emission sources, they are reached by trace elements and POPs through atmospheric and oceanic transport (Fitzgerald et al., 2007; Galbán-Malagón et al., 2013). Many contaminants, such as mercury (Hg) and POPs bioaccumulate in organisms and biomagnify in food webs (Morel et al., 1998; Fisk et al., 2001). Thus, polar marine predators usually bear high burdens of contaminants (Bustnes et al., 2003; Bargagli, 2008), with exposure being governed by various factors such as foraging habitat and trophic position (Fisk et al., 2001; Carravieri et al., 2013). Seabirds are often considered to be ideal models to biomonitor contaminants in the marine environment, since they forage over large geographic areas and feed at different trophic levels (Furness and Camphuysen, 1997). In contrast to Arctic species (e.g., Braune et al., 2005; Dietz et al., 2009), contaminant exposure of Southern Ocean seabirds has received little attention, although pioneer studies have reported a wide diversity of compounds in their tissues (Bocher et al., 2003; Tao et al., 2006; Anderson et al., 2010).

Several tissues have been used to evaluate seabird contamination, particularly feathers (e.g., Bustnes et al., 2002; Seco Pon et al., 2011), blood (e.g., González-Solís et al., 2002; Bustnes et al., 2007) and soft tissues such as liver (e.g., Colabuono et al., 2012; Jerez et al., 2013). The interpretation of contaminant burdens in these tissues depends on the understanding of contaminant dynamics within the whole organism. For instance, blood has a transport role for contaminants, and circulating concentrations are believed to reflect short- 
term dietary exposure (Burger and Gochfeld, 1997). On the other hand, the liver and kidney are specifically involved in contaminant detoxification and/or storage, while muscles could function as a temporary storage tissue (Lewis and Furness, 1991). Finally, feathers are known to sequester both metallic and organic contaminants during their synthesis (Burger, 1993; García-Fernández et al., 2013). Overall, however, these mechanisms are still poorly known for the large majority of environmental contaminants. Namely, there have been only few comprehensive studies that have simultaneously quantified trace elements and POPs in a suite of seabird tissues, and that have investigated between-contaminant and between-tissue relationships (Eagles-Smith et al., 2008; Colabuono et al., 2012). Data are particularly lacking for low trophic level seabirds, because they usually bear lighter burdens of contaminants than top predators, with residues being more difficult to detect.

The present study describes the concentrations of 14 trace elements and 30 POPs (seven polychlorinated biphenyls, PCBs; 12 organochlorine pesticides, OCPs; and 11 polybrominated diphenyl ethers, PBDEs) in several internal tissues and in feathers of 10 Antarctic prions (Pachyptila desolata) from Kerguelen Islands, a remote subantarctic archipelago in the southern Indian Ocean. The Antarctic prion breeds in Antarctic and subantarctic islands, with important populations at South Georgia (southern Atlantic Ocean), Auckland (southern Pacific Ocean) and Kerguelen Islands (Weimerskirch et al., 1989; Marchant and Higgins, 1990). At the latter locality, breeding Antarctic prions forage in cold waters where they prey primarily on swarming crustaceans (pelagic amphipods) to feed their chicks (Weimerskirch et al., 1999; Cherel et al., 2002). The composition of stomach oil indicates that adults also prey on mid-water fish when they feed for themselves (Connan et al., 2007). During the inter-breeding season, birds shift north to the warmer subtropical waters where they moult (Quillfeldt et al., 2015). 
Our main goal was to investigate the contaminant distribution pattern, and inter-tissue and inter-contaminant relationships, in order to depict co-exposure and/or similar bioaccumulation and detoxification patterns among contaminants. Furthermore, correlations of soft tissue burdens with blood and/or feather concentrations is necessary to validate the use of these tissues as appropriate proxies of internal contamination, which has surprisingly received little attention in polar seabirds (Henriksen et al., 1998; Bustnes et al., 2003). Based on previous knowledge (Bocher et al., 2003), we expected the liver to bear high contaminant burdens when compared to other organs, and feathers to present high $\mathrm{Hg}$ concentrations, considering their excretory role (Braune and Gaskin, 1987). Given the relatively low trophic level, and thus potentially low contaminant exposure of Antarctic prions, we expected overall low contaminant concentrations in this species when compared to higher trophic level seabirds from the same environments.

\section{Materials and methods}

\subsection{Sample collection and preparation}

Ten freshly dead Antarctic prions trapped in the vegetation (Acaena adscendens) were opportunistically collected on January $26^{\text {th }}, 2012$, on the Kerguelen archipelago $\left(49^{\circ} 21^{\prime}\right.$ S, $\left.70^{\circ} 18^{\prime} \mathrm{E}\right)$, southern Indian Ocean. Only intact specimens were collected and then stored at $20^{\circ} \mathrm{C}$ until dissection. Age and breeding status of birds were not known. However, because in Kerguelen Islands Antarctic prions' eggs are laid in December (incubation of the single white egg takes 44-46 days) and chicks fledge at 45-55 days old (Weimerskirch et al., 1989) these birds cannot be newly fledged chicks.

During necropsies, internal tissues (liver, kidneys and pectoral muscle) were sampled, weighed and wrapped individually in plastic bags and in aluminium foils for trace element and POP analyses, respectively. The stomachs were also dissected in order to check their 
contents. Plastic debris were found in five individuals. Clotted blood was collected from heart auricles and stored in microtubes at $-20{ }^{\circ} \mathrm{C}$. Four body feathers were pulled out from the lower back and stored dry in plastic bags. Birds were first sexed during necropsies by visual gonad examination. Sex was then confirmed using the molecular method described by Fridolfsson and Ellegren (1999). Prior to chemical analyses, internal tissues and blood were freeze-dried, ground to powder and then stored in plastic and glass tubes for trace element and POP analyses, respectively. Feathers were washed to remove surface dirt and adsorbed contaminants in a chloroform-methanol solution and then oven dried as described by Carravieri et al. (2013). For each individual, the four body feathers were pooled to limit potential inter-feather differences in trace element concentrations (Carravieri et al., 2014a); feathers were homogenised by cutting them with scissors into small fragments $(1-2 \mathrm{~mm})$. Samples were weighed before and after freeze drying to calculate water content (moisture, see Table S1, Supplementary material).

\subsection{Analyses of trace elements}

Trace elements were determined in blood, liver, kidney, muscle and feathers. Total $\mathrm{Hg}$ analysis was carried out with an advanced mercury analyser (ALTEC AMA 254) on dried tissue aliquots (2-4 mg) following Blévin et al. (2013). All analyses were repeated 2-3 times

until having a relative standard deviation b10\%. Accuracy was checked using TORT-2 Lobster Hepatopancreas (NRC, Canada) as certified reference material (CRM) with a certified $\mathrm{Hg}$ concentration of $0.27 \pm 0.06 \mu \mathrm{g} \mathrm{g}^{-1}$ dry weight $(\mathrm{dw})$. Our measured values were $0.267 \pm$ $0.006 \mu \mathrm{g} \mathrm{g}^{-1} \mathrm{dw}(\mathrm{n}=18)$. Thirteen other elements (silver, Ag; arsenic, As; cadmium, Cd; cobalt, $\mathrm{Co}$; chromium, $\mathrm{Cr}$; copper, $\mathrm{Cu}$; iron, $\mathrm{Fe}$; manganese, $\mathrm{Mn}$; nickel, $\mathrm{Ni}$; lead, $\mathrm{Pb}$; selenium, Se; vanadium, V; and zinc, Zn) were analysed using a Varian Vista-Pro ICP-OES and a Thermo Fisher Scientific X Series 2 ICP-MS (following Métian et al., 2008). Aliquots 
of the biological samples (30-300 mg) were digested with $6 \mathrm{ml} 67-70 \% \mathrm{HNO}_{3}$ and $2 \mathrm{ml} \mathrm{34-}$ $37 \% \mathrm{HCl}$ (Fisher Scientific, trace element grade quality), except for feathers (1.8 ml HNO3 and $0.6 \mathrm{ml} \mathrm{HCl}$ ). Acidic digestion was carried out overnight at room temperature and then in a Milestone microwave (30 min with constantly increasing temperature up to $120{ }^{\circ} \mathrm{C}$, and finally $15 \mathrm{~min}$ at this maximal temperature). Each sample was completed to $50 \mathrm{ml}$ (15 $\mathrm{ml}$ for feathers) with milli-Q water. Three control samples (two CRM, and one blank) treated and analysed in the same way as the samples were included in each analytical batch. CRMs were DOLT-4 dogfish liver (NRC, Canada) and TORT-2 (NRC, Canada). The results were in good agreement with CRMs, with a mean recovery rate of $87-104 \%$ for DOLT -4 and $88-102 \%$ for TORT-2. The limits of detection (LoD) are given in Table S2, Supplementary material. Trace element concentrations are expressed in $\mu \mathrm{g} \mathrm{g}^{-1} \mathrm{dw}$.

\subsection{Analyses of persistent organic pollutants (POPs)}

POPs were analysed in liver, kidney and muscle. Seven indicators PCBs (CBs $28+50$, $52,101,118,138,153$, and 180) were targeted. These compounds are predominantly present in biotic and abiotic matrices and were thus recognised as compounds representative of the whole group of PCBs by the Agency for Toxic Substances and Disease Registry (ATSDR, 2000). Additionally, 12 OCPs (HCB, $\gamma$-HCH, heptachlor, cis-chlordane, trans-nonachlor, 2,4'DDE, 4,4'-DDE, 2,4'-DDD, 4,4'-DDD, 2,4'-DDT, 4,4'-DDT and mirex) and 11 PBDEs (BDEs $17,28,47,49+71,66,99,100,153,154,183$ and 209) were also assayed. PCB and OCP standard solutions were provided by NIST (via LGC Standards, Molsheim, France, see Table S3, Supplementary material) while PBDE standards were provided by Wellington Laboratories (via BCP Instruments, Irigny, France). Analytes were extracted using microwave assisted extraction (Milestone Start-E) with $10 \mathrm{ml}$ of dichloromethane on homogenised freeze-dried samples (0.2-1.0 g) spiked with internal standards: CBs 30, 103, 155 and 198, F- 
BDE-47 (Chiron, via BCP Instruments), DDTd8 (supplied by Dr. Ehrenstorfer), BDE-181 (Wellington Laboratories) and BB-209 (LGC Standards, Molsheim, France) (5-8 ng each) (Müller et al., 2001; Tapie et al., 2008). Extracts were reconcentrated into $300 \mu \mathrm{l}$ of isooctane, using a RapidVap vacuum evaporation system from Labconco (Kansas City, MO, USA) and a nitrogen flow, prior to purification on acid silica gel column. PCBs, OCPs and PBDEs were eluted with $3 \times 5 \mathrm{ml}$ of pentane/dichloromethane (90/10; v/v), and final extracts were concentrated and transferred into isooctane as solvent keeper. Octachloronaphthalene (1 ng) was added as performance standard to quantify internal standards. Lipids were determined by gravimetry after filtration and evaporation of an aliquot of the DCM extract. PCBs and OCPs analyses were carried out on an HP 5890 series II gas chromatograph from Hewlett-Packard (Avondale, CA, USA) coupled to a 63Ni electron capture detector (ECD). A capillary column HP5-MS (Agilent Technologies, Massy, France) was used $(30 \mathrm{~m} \times 0.25 \mathrm{~mm} \times 0.25 \mu \mathrm{m})$. Helium (He, 5.6 quality, Linde Gas, Toulouse, France) was used as carrier gas at a flow rate of $1 \mathrm{ml} \mathrm{min} \mathrm{m}^{-1}$ and nitrogen (N2, 5.0 quality, Linde Gas, Toulouse, France) was used as make up gas $\left(60 \mathrm{mlmin}^{-1}\right)$. The injector temperature was $280{ }^{\circ} \mathrm{C}$ and detector temperature was 320 ${ }^{\circ} \mathrm{C}$ (Tapie et al., 2011).

PBDEs were analysed by gas chromatography coupled with mass spectrometry operated in negative chemical ionisation (GC-NCI-MS). Analyses were carried out using an Agilent 6890N GC coupled to a Quattro Micro GC (Waters Micromass). The system was fitted with J\&W HP-5MS analytical column $(15 \mathrm{~m}, 0.25 \mathrm{~mm}$ ID $\times 0.25 \mu \mathrm{m}$ film thickness; Agilent Technologies, Massy, France) and operated in pulsed splitless injection mode (1.7 bar, 3 min) with an injector temperature of $280{ }^{\circ} \mathrm{C}$. The helium carrier gas flow rate was 1.8 $\mathrm{ml} \mathrm{min}{ }^{-1}$ and temperature programme was as follows: $90{ }^{\circ} \mathrm{C}(0.1 \mathrm{~min}), 185^{\circ} \mathrm{C}\left(25^{\circ} \mathrm{C} \mathrm{min}^{-1}\right)$, $275^{\circ} \mathrm{C}\left(15^{\circ} \mathrm{C} \min ^{-1}\right)$, and $305^{\circ} \mathrm{C}\left(35^{\circ} \mathrm{C} \min ^{-1}\right.$, held for $\left.2 \mathrm{~min}\right)$. The transfer line temperature and the source temperature were set at $300{ }^{\circ} \mathrm{C}$ and $250{ }^{\circ} \mathrm{C}$, respectively. Ions were monitored 
in SIM mode using a single acquisition window, with a dwell time set at $50 \mathrm{~ms}$. [Br]- $(\mathrm{m} / \mathrm{z} 79$ and 81) was monitored for all PBDEs while m/z 402 and 404 were monitored for OCN.

PCBs, OCPs and PBDEs compounds were quantified relative to internal standards. CBs 30, 103, 155 and 198 were used to quantify PCBs, and DDTd8 was used to quantify OCPs, whereas F-BDE-47, BDE-181 and BB-209 were used to quantify PBDEs. A syringe standard (octachloronaphthalene) was used to quantify internal standards and verify recoveries for each sample. Quality control consisted of the analysis of solvent procedural blanks, reproducibility and repeatability tests, injection of standard solutions as unknowns, and CRM analysis (SRM 1947, National Institute of Standards and Technology, USA) for PCBs, OCPs (except for $\gamma$-HCH, heptachlor and cischlordane), and PBDEs (except for BDEs 17, 18, 49, 71, 183 and 209). Procedure details are given in Tapie et al. (2008). As described by Labadie et al. (2010), POP concentrations were blank corrected and the LoD was derived from the blank value variability. For analytes that were not detected in blanks, LoD was determined as the concentration with a signal to noise ratio of three. Regardless of the approach used for LoD calculation, the LoQ was set at three times the LoD for all analytes. LoD and LoQ values are reported in Table S4, Supplementary material.

\subsection{Statistical analyses}

PCBs, OCPs and PBDEs compounds were quantified relative to internal standards. CBs 30, 103, 155 and 198 were used to quantify PCBs, and DDTd8 was used to quantify OCPs, whereas F-BDE-47, BDE- 181 and BB-209 were used to quantify PBDEs. A syringe standard (octachloronaphthalene) was used to quantify internal standards and verify recoveries for each sample. Quality control consisted of the analysis of solvent procedural blanks, reproducibility and repeatability tests, injection of standard solutions as unknowns, and CRM analysis (SRM 1947, National Institute of Standards and Technology, USA) for 
PCBs, OCPs (except for $\gamma-\mathrm{HCH}$, heptachlor and cischlordane), and PBDEs (except for BDEs 17, 18, 49, 71, 183 and 209). Procedure details are given in Tapie et al. (2008). As described by Labadie et al. (2010), POP concentrations were blank corrected and the LoD was derived from the blank value variability. For analytes that were not detected in blanks, LoD was determined as the concentration with a signal to noise ratio of three. Regardless of the approach used for LoD calculation, the LoQ was set at three times the LoD for all analytes. LoD and LoQ values are reported in Table S4, Supplementary material.

\section{Results}

\subsection{Influence of sex on trace element and POP concentrations}

No consistent gender differences were found in tissue concentrations of trace elements and POPs. Hence, female $(n=5)$ and male $(n=5)$ data were pooled for subsequent statistical analyses. Only five out of 101 comparisons were significantly different, namely (i) higher As and Cd concentrations in blood (respectively Wilcoxon test, $\mathrm{W}=1, \mathrm{p}=0.019 ; \mathrm{W}=1.5, \mathrm{p}=$ 0.027), and (ii) lower $\mathrm{Hg}$ concentrations in blood ( $\mathrm{W}=25, \mathrm{p}=0.012)$, kidney $(\mathrm{W}=24, \mathrm{p}=$ $0.016)$ and muscle $(\mathrm{W}=22.5, \mathrm{p}=0.046)$ and slightly lower in liver $(\mathrm{W}=21, \mathrm{p}=0.094)$ of females than males.

\subsection{Tissue distribution of trace elements}

Of all the targeted 14 trace elements, only $\mathrm{Ag}, \mathrm{Pb}$ and $\mathrm{V}$ had concentrations below the LoD in all or almost all tissues (Table 1). Kidney and feathers presented the highest concentrations of the non-essential elements $\mathrm{Cd}$ and $\mathrm{Hg}$, respectively (Wilcoxon test, $0<\mathrm{W}<$ 100, $0.002<\mathrm{p}<0.0002$ ) (Fig. 1). Liver presented the highest concentrations of the essential elements As, Fe, Mn and Zn (Wilcoxon or t tests, $81<\mathrm{W}<100$ or $6.48<\mathrm{t}<15.7$, all $\mathrm{p}<$ 
0.0001), muscle had the highest amount of $\mathrm{Cu}(95<\mathrm{W}<100$, all $\mathrm{p}<0.0001)$ and blood showed the highest amount of $\operatorname{Se}(1.18<\mathrm{t}<8.99,0.0001<\mathrm{p}<0.015)$.

\subsection{Between-tissue and between-trace element relationships}

Between-tissue relationships were investigated for each trace element. Only 11 correlations were significant out of 140 , of which 8 were between blood and soft tissues. Significant positive relationships were found for $\mathrm{Hg}$ between blood and all soft tissues (Spearman test, $0.694<$ rho $<0.776,0.008<\mathrm{p}<0.026$ ) (Fig. 2), and between muscle and

liver and kidney (rho $=0.661$ and $0.646, p=0.038$ and 0.043 , respectively). Significant positive correlations were also found for As between blood and kidney (rho $=0.778, \mathrm{p}=$ 0.009). Between-element relationships were investigated within each tissue. Concerning nonessential trace elements, there were only significant relationships between $\mathrm{Cd}$ and $\mathrm{Hg}$ in liver (rho=0.693, $\mathrm{p}=0.026$ ). Among essential elements, correlations were particularly strong between $\mathrm{Cr}$ and $\mathrm{Ni}$ in liver, kidney and muscle $(0.889<$ rho $<0.957,0.0001<\mathrm{p}<0.0006)$. Other significant relationships involved $\mathrm{Cu}, \mathrm{Fe}, \mathrm{Mn}$ and $\mathrm{Zn}$ in blood $(0.711<$ rho $<0.862$, $0.004<\mathrm{p}<0.018)$, liver $(0.713<\mathrm{p}<0.764,0.013<\mathrm{p}<0.041)$ and muscle $(0.841<$ rho $<$ $0.934,0.0003<\mathrm{p}<0.004)$. Cd was involved in the majority of relationships between essential and non-essential elements in all tissues (for example in blood: $\mathrm{As}-\mathrm{Cd}, \mathrm{Cd}-\mathrm{Cu}, \mathrm{Cd}-\mathrm{Fe}, \mathrm{Cd}-$ $\mathrm{Mn}$ and $\mathrm{Cd}-\mathrm{Zn}$; and in muscle: $\mathrm{Cd}-\mathrm{Cu}, \mathrm{Cd}-\mathrm{Fe}, \mathrm{Cd}-\mathrm{Mn}$ and $\mathrm{Cd}-\mathrm{Zn})$.

\subsection{Tissue distribution of POPs}

Of the 30 targeted POPs, only the following were below the LoD in all samples: 2,4'DDD, BDE-17, BDE-49 + 71, BDE-66, and BDE-100 (Table 2). In all tissues, the PCB pattern was dominated by CB-153 N CB-138 N CB-118, which together accounted for more than $75 \%$ of the PCB burden. The prevalent OCPs were 4,4'-DDE N mirex N HCB, totalling 
more than $90 \%$ of the OCP burden. Among PBDEs, the highest concentrations were reported for BDE-209, but only three individuals had quantifiable levels. In contrast to PCBs and PBDEs, OCP concentrations varied among tissues (Fig. 3). Namely, $\gamma-\mathrm{HCH}, 2,4^{\prime}$-DDE, cischlordane and trans-nonachlor concentrations were higher in liver and muscle than in kidney (Wilcoxon test, $22<\mathrm{W}<83,0.015<\mathrm{p}<0.045$ ), and HCB concentrations were higher in liver and kidney than in muscle $(7<\mathrm{W}<18,0.0005<\mathrm{p}<0.015)$.

\subsection{Between-tissue and between-POP relationships}

All between-tissue correlations were significant for $\Sigma_{30}$ POPs and $\Sigma_{12}$ OCPs (Spearman test, rho $>0.7, \mathrm{p}<0.045)$. Several individual PCB and OCP compounds were also significantly correlated between tissues, in particular between liver and kidney (4,4'-DDE, mirex, HCB, CB-138, CB-153 and CB-180, Fig. 4). Relationships between POPs within each tissue were also determined. $\Sigma_{7} \mathrm{PCBs}$ and $\Sigma_{12} \mathrm{OCPs}$ were significantly correlated in muscle, kidney and liver $(0.842<$ rho $<0.879,0.002<\mathrm{p}<0.004)$. Significant relationships were found within two groups of compounds. The first group consisted of 4,4'-DDE, mirex, HCB, trans-nonachlor, CB-138, CB-153 and CB-180, which correlated in liver, kidney and muscle (Fig. 5). Additionally, 4,4'-DDDwas strongly correlated to these compounds in muscle $(0.873$ $<$ rho $<0.932,0.001<\mathrm{p}<0.004)$. The second group consisted of $\gamma-\mathrm{HCH}, 2,4^{\prime}-\mathrm{DDE}$, cischlordane, CB-118 and BDE-28, which correlated in liver $(0.951<$ rho $<0.644,0.001<\mathrm{p}<$ 0.004). In muscle, significant correlations were only found between $\gamma-\mathrm{HCH}$ and 2,4'-DDE $($ rho $=0.832, \mathrm{p}=0.001), 4,4^{\prime}-\mathrm{DDT}$ and $2,4^{\prime}-\mathrm{DDE}(\mathrm{rho}=0.673, \mathrm{p}=0.028)$, and between cischlordane and CB-118 (rho $=0.861, \mathrm{p}=0.002)$. The same correlations were highlighted using concentrations normalised by lipid content. 


\section{Discussion}

Contaminant levels of procellariiform seabirds in the southern Indian Ocean have been previously investigated, focussing on trace elements (Hindell et al., 1999; Bocher et al., 2003; Blévin et al., 2013; Carravieri et al., 2013, 2014a, 2014b, 2014c) and POPs (Guruge et al., 2001a, 2001b; Tanabe et al., 2004; Carravieri et al., 2014b). However, to our knowledge, the present study is the first to consider such a large number of contaminants $(n=30)$, in particular PBDEs, measured on a significant number of tissues $(n=3$ to 5$)$ of the same individual birds $(n=10)$. The extent of metallic and organic contamination in the species is remarkable when considering both its small size and relatively low trophic position.

\subsection{Tissue distribution of trace elements: comparison with other seabirds and other areas}

Essential element concentrations (As, $\mathrm{Co}, \mathrm{Cu}, \mathrm{Fe}, \mathrm{Mn}, \mathrm{Se}$ and $\mathrm{Zn}$ ) in internal tissues and feathers were in accordance with most previous studies on Southern Ocean Procellariiformes (Lock et al., 1992; Bocher et al., 2003; Seco Pon et al., 2011; Jerez et al., 2013). Surprisingly however, $\mathrm{Cu}$ and $\mathrm{Fe}$ concentrations in feathers were 30 and 100 times lower, respectively, than those observed in Antarctic prions from South Georgia (Anderson et al., 2010). In this last study, $\mathrm{Cu}$ and $\mathrm{Fe}$ concentrations were largely variable between individuals. Moreover, feathers were cleaned, but not washed prior to analysis, which may have introduced some errors into trace element results (Anderson et al., 2009), especially when considering that Antarctic prions nest in burrows or rock crevices. In contrast to soft tissues and feathers, essential element concentrations in blood were not in accordance with the literature (e.g., González-Solís et al., 2002; Anderson et al., 2010),with concentrations being higher than expected for $\mathrm{Cu}, \mathrm{Mn}$ and $\mathrm{Zn}$, and lower for Fe. This could be linked to the fact that blood was collected from heart auricles after death, instead of being sampled from living animals. The birds of the present study probably died of exhaustion, which could influence 
blood essential element concentrations. Previous research showed that body condition is one of the most important factors influencing essential element concentrations in blood, especially in the case of $\mathrm{Cu}, \mathrm{Fe}$ and $\mathrm{Zn}$ (Debacker et al., 2000; Malinga et al., 2010). No major differences, except for blood, were found in essential element concentrations between Antarctic prions and seabirds feeding at higher trophic levels, such as albatrosses (e.g., Kim et al., 1998; Seco Pon et al., 2011). This is not surprising since essential elements are submitted to homeostatic control, with their absorption being regulated according to the nutritional requirements of the individual (Walsh, 1990). As expected, Fe, Mn and Zn were preferentially accumulated in the liver, where they appeared to be closely regulated (Elliott and Scheuhammer, 1997). In contrast and as previously observed by Bocher et al. (2003), Cu concentration was higher in muscle than in liver. This accumulation pattern has been reported in Barau's petrels (Pterodroma baraui) and Audubon's shearwaters (Puffinus lherminieri bailloni) from Réunion Island (Kojadinovic et al., 2007a). Se distribution in prion soft tissues is in agreement with previous works showing that this essential element is preferentially retained in kidney (e.g., Kim et al., 1998; Mendes et al., 2008). As already shown in Antarctic prions and other planktonophagous petrels at South Georgia (Anderson et al., 2010), blood Se concentrations were high, especially in comparison to wandering albatrosses from the southern Indian Ocean (Carravieri et al., 2014b). At the Kerguelen Islands, Antarctic prions feed largely on the pelagic amphipod Themisto gaudichaudii (Cherel et al., 2002), which bear large quantities of Se (Anderson et al., 2010). This suggests that the large Se burden in Antarctic prions' blood is diet-derived.

Tissue concentrations of the non-essential elements $\mathrm{Cd}, \mathrm{Hg}$ and $\mathrm{Pb}$ were in the same range of those found in small planktonophagous petrels at Kerguelen Islands (Bocher et al., 2003) and in other Procellariiformes worldwide (Kim et al., 1998; Kojadinovic et al., 2007a; Anderson et al., 2009, 2010; Bond and Lavers, 2011). Pb concentrations were below the LoQ 
in all soft tissues but not in the feathers of Antarctic prions, as previously shown in seabirds (Jerez et al., 2013), likely because this non-essential element is preferentially accumulated in bone or feathers rather than in soft tissues (Scheuhammer, 1987). Antarctic prion Cd concentrations were higher than those found in fish-eating seabirds (Agusa et al., 2005; Mendes et al., 2008). Blood Cd concentrations were notably higher than those of the wandering albatross from the same subantarctic environments (Carravieri et al., 2014b). This is not surprising because $\mathrm{Cd}$ is not biomagnified through marine food webs, thus resulting in some cases in higher Cd concentrations in consumers with lower trophic positions (SanchezHernandez, 2000). The high Cd burden of Antarctic prions could be explained by their significant consumption of $T$. gaudichaudii (Cherel et al., 2002), which shows high Cd concentrations in Kerguelen waters (Bocher et al., 2003). The preferential Cd accumulation in kidney as shown here, is a usual trend in seabirds (Nam et al., 2005; Kojadinovic et al., 2007a; Mendes et al., 2008), and according to Scheuhammer (1987), a higher Cd concentration in kidney than in liver usually indicates chronic exposure to low $\mathrm{Cd}$ levels. Whatever the tissue type, $\mathrm{Hg}$ concentrations were lower in Antarctic prions than in fish- or squid-eating seabirds, such as albatrosses (Anderson et al., 2009; Carravieri et al., 2014b; Bustamante et al. 2016). This is consistent with $\mathrm{Hg}$ biomagnification within food webs, which leaves top predators at high risk of exposure through food intake (Furness and Camphuysen, 1997; Morel et al., 1998). As expected, the highest $\mathrm{Hg}$ concentration was found in feathers, since a large proportion of the $\mathrm{Hg}$ body burden can be excreted in the plumage during moult (up to 93\%, Braune and Gaskin, 1987). Among soft tissues, liver presented the highest $\mathrm{Hg}$ concentrations, due to its important role in $\mathrm{Hg}$ detoxification and storage (Monteiro and Furness, 1995; Kim et al., 1998). 
4.2. Tissue distribution and relative proportion of POPs: comparison with other seabirds and other areas

Overall, POP concentrations in Antarctic prions' tissues were low compared to the Southern Ocean Procellariiformes studied so far. Since POPs biomagnify in food webs, their accumulation in seabirds depends largely on their diet and trophic position (Borgå et al., 2001, 2005; Buckman et al., 2004). Accordingly, $\Sigma_{7}$ PCBs concentrations in Antarctic prions were similar to those of Antarctic petrels (Thalassoica antarctica) and Cape petrels (Daption capense) (Van den Brink, 1997), which also feed mainly on crustaceans. $\Sigma_{7} \mathrm{PCBs}$ concentrations were lower than those of seabirds feeding at higher trophic levels, such as albatrosses and petrels (Guruge et al., 2001a, 2001b; Colabuono et al., 2012). Similarly, $\Sigma_{12} \mathrm{OCPs}$ concentrations in Antarctic prions were lower than those detected in albatrosses or skuas (Guruge et al., 2001a; Corsolini et al., 2002), and similar to those in low trophic levels seabirds (Buckman et al., 2004; Mallory et al., 2004). Concentrations of OCPs and PCB congeners tended to be higher in liver (Table 2), which is consistent with its high metabolic activity and its role in lipophilic pollutant metabolism (Malcolmet al., 2003). Overall, the PCBs were largely less abundant than OCPs in all tissues (Fig. 6), as previously shown in the plasma of Crozet wandering albatrosses (Carravieri et al., 2014b). This pattern is probably linked to the large distance of these environments to industrialised zones and to the fact that PCBs were used in a less dispersive manner than OCPs. The high contribution of CBs 138, 153 and 180 to the PCB burden in Antarctic prions' tissues from Kerguelen Islands is similar to earlier data from various Southern Ocean seabirds (e.g., Court et al., 1997; Guruge et al., 2001a; Corsolini et al., 2011, Carravieri et al., 2014b) and Arctic regions (e.g., Henriksen et al., 1998, 2000; Buckman et al., 2004). Birds' capacity to metabolise PCBs decreases with increasing degree of PCB chlorination (Maervoet et al., 2004). Therefore, more chlorinated compounds like CBs 118, 138, 153 and 180 tend to be accumulated, while CBs 52 or 101 are 
more prone to be metabolised. The contribution of individual OCPs was also similar to earlier studies. 4,4'-DDE dominated the OCP pattern in Arctic and Antarctic seabirds, followed by HCB and mirex (Henriksen et al., 2000; Borgå et al., 2001; Goerke et al., 2004; Carravieri et al., 2014b). The particularly strong occurrence of 4,4'-DDE to OCPs in seabirds may be due to both dietary accumulation and DDT metabolism (Borgå et al., 2001). As shown by Sagerup et al. (2009), cis-chlordane, trans-nonachlor and $\gamma-\mathrm{HCH}$ presented lower liver concentrations than the most predominant OCPs, since these compounds seem to be more easily metabolised and excreted (Borgå et al., 2001). Typical PBDE patterns in wildlife, including seabirds, are dominated by BDE-47, followed by nearly equal contributions of BDEs 99, 100, 153 and 154 (Vorkamp et al., 2004; Fängström et al., 2005; Verreault et al., 2010). Surprisingly, BDE-183 and BDE-209 were detected in all tissues of some Antarctic prions, with BDE-209 concentrations being very high. The latter is the main component of decaBDE, a commercial mixture, which production and use is not regulated by the Stockholm Convention on POPs (www.pops.int). BDE-183 and BDE-209 have been recently documented in the tissues of some pelagic seabirds and marine mammals (Fängström et al., 2005; Jenssen et al., 2007; Tanaka et al., 2013). The presence of high brominated compounds in seabirds from these remote environments is puzzling, but exposure in northern wintering areas or along the migratory routes of some individual prions (Quillfeldt et al., 2015) is likely. Furthermore, BDE-183 and BDE-209 have a strong affinity to particles and have been detected in marine plastic debris, including at high concentrations (Hirai et al., 2001). Seabirds are prone to ingest plastic debris, mistaking them for prey (e.g., Ryan et al., 2009) and plastic-mediated exposure to BDE-183 and BDE-209 has already been hypothesised in short-tailed shearwaters (Puffinus tenuirostris) (Tanaka et al., 2013). Plastic pollution has been recently identified as a threat to subantarctic and Antarctic environments (Ivar do Sul et al., 2011). Plastic debris were found in five of our 10 individuals, confirming that this species is indeed prone to plastic 
ingestion. This result supports the hypothesis that the exposure to BDE-183 and BDE-209 in Antarctic prions from Kerguelen Islands could be plastic-mediated.

\subsection{Relationships among tissues and between contaminants}

In the present study, a large number of positive correlations were observed between trace elements in Antarctic prions' tissues, in broad agreement with the few previous investigations in seabirds (e.g., Nam et al., 2005; Mendes et al., 2008; Jerez et al., 2013). Concentrations of $\mathrm{Cu}, \mathrm{Fe}, \mathrm{Mn}$ and $\mathrm{Zn}$ presented positive relationships $(\mathrm{Cu}-\mathrm{Fe}, \mathrm{Cu}-\mathrm{Mn}, \mathrm{Cu}-$ $\mathrm{Zn}, \mathrm{Fe}-\mathrm{Mn}, \mathrm{Fe}-\mathrm{Zn}$ and $\mathrm{Mn}-\mathrm{Zn}$ ), especially in liver and muscle, which may indicate common sources of exposure, similar storage pathways, regulation and/or detoxification processes (e.g., Jerez et al., 2013). Additionally, these elements presented strong relationships with Cd that can be explained by $\mathrm{Cd}$ having similar regulatory mechanisms to $\mathrm{Cu}$ and $\mathrm{Zn}$, such as detoxification by binding to metallothioneins and insolubilisation in mineral concretions (Ikemoto et al., 2004; Kojadinovic et al., 2007b; Lucia et al., 2009, 2012). Feathers and blood are the most targeted tissues to quantify trace element concentrations in birds mainly because they can be easily and non-destructively sampled on a large number of live individuals (e.g., Burger and Gochfeld, 2004). Importantly, the proportion of the body burden stored in the feathers is relatively constant for some elements, particularly $\mathrm{Hg}$ (Burger, 1993; Monteiro and Furness, 1995). Here, feather trace element concentrations, and particularly $\mathrm{Hg}$, were not significantly correlated to the other tissues. The likely explanation of this discrepancy is a temporal mismatch between concentrations in metabolically active versus inactive tissues (soft tissues and feathers, respectively). Once the feather is formed, the blood supply atrophies, with no further element being deposited. Hence, feather $\mathrm{Hg}$ concentrations in Antarctic prions had not changed since their last moult, whereas $\mathrm{Hg}$ concentrations in the other tissues had progressively increased through dietary intake (bioaccumulation). Thus, 
feather $\mathrm{Hg}$ concentration reflects $\mathrm{Hg}$ levels of internal organs at the time of the previous moult, but not at the time of sampling. $\mathrm{Cd}$ and $\mathrm{Pb}$ are firmly bound to organic and inorganic compounds in kidney and bone, respectively, and thus only enter feathers in trace amounts (Walsh, 1990; Furness, 1993; Stewart et al., 1994). Therefore, it would be better to consider cautiously the use of feather concentrations to predict soft tissues burdens for these two nonessential elements (Nam et al., 2005). On the other hand, blood $\mathrm{Hg}$ concentration (Fig. 2), and to a lesser extent blood As concentration, appeared to be very good indicators of soft tissue concentrations.

Little information is available on POP inter-tissue and inter-compound relationships. In Antarctic prions, some PCBs (CBs 118, 138, 153 and 180) and OCPs (HCB, 4,4'-DDE and mirex) presented strong positive inter-tissue correlations. This pattern has been reported in seabirds including albatrosses and petrels (e.g., Henriksen et al., 1998; Colabuono et al., 2012). These compounds are highly persistent, highly lipophilic, and slowly metabolised (e.g., Borgå et al., 2001). Therefore, they partition among the various tissue lipid fractions relatively quickly to establish equilibrium (Norstrom, 2002). The most persistent POPs such as CB 153 and 180 were also highly correlated within each tissue (Fig. 5), likely indicating coexposure. Interestingly, significant positive relationships were also reported between PCBs and OCPs in all tissues (e.g., between 4'-DDE, mirex, HCB, trans-nonachlor, CB-138, CB153 and CB-180). Correlations between POPs of different chemical families have previously been documented in seabirds' plasma, and strongly suggest that contaminant exposure happens by feeding on prey containing similar relative amounts of both PCBs and DDTs (Bustnes et al., 2001; Mora et al., 1993; Finkelstein et al., 2006). 


\section{Conclusions}

The present study shows that relatively low trophic level seabirds (zooplankton-eaters) breeding in the remote southern Indian Ocean are exposed to a wide range of environmental contaminants. This study corroborates previous results showing that an amphipod-rich diet is associated with a high $\mathrm{Cd}$ and $\mathrm{Se}$ intake, and low $\mathrm{Hg}$ exposure, in small petrels. Feeding at low trophic levels surprisingly implied the occurrence of a variety of OCPs and PBDEs in internal tissues, which merits complementary studies on the contamination of Antarctic prions' prey. Results of our work validate the use of blood as a good indicator of internal tissue concentrations of $\mathrm{As}$ and $\mathrm{Hg}$ in small petrels. The lack of correlations of $\mathrm{Hg}$ and other trace element concentration between feathers and soft tissues does not indicate that feathers are not good indicators of internal contamination, but rather that the temporal integration of contaminants into feathers must be carefully considered. Further studies investigating feather and internal contaminant concentrations during moult are highly needed to understand the mechanism of excretion, in particular for POPs.

\section{Acknowledgements}

The authors thank Kévin Coustaut and Elodie Camprasse for collecting the Antarctic prions in the field, and C. Barbraud and L. Thiers for helpful suggestions in statistical analyses. The authors are grateful to the Plateforme Analyses Elémentaires for the access to their analytical facilities. The present work was supported financially and logistically by the Région PoitouCharentes through a $\mathrm{PhD}$ grant to $\mathrm{AC}$, and by the Agence Nationale de la Recherche (programme POLARTOP, O. Chastel), the Institut Polaire Français Paul Emile Victor (IPEV, programmeno. 109, H. Weimerskirch) and the Terres Australes et Antarctiques Françaises (TAAF). The Aquitaine Region and the European Union (CPER A2E project) are acknowledged for their financial support. Europe is moving in Aquitaine with the European Regional Development Fund. 


\section{References}

Agusa T, Matsumoto T, Ikemoto T, Anan Y, Kubota R, Yasunaga G, Kunito T, Tanabe S, Ogi H, Shibata Y. Body distribution of trace elements in Black-tailed gulls from Rishiri Island, Japan: age-dependent accumulation and transfer to feathers and eggs. Environmental Chemistry. 2005;24(9):2107-20.

AMAP. AMAP Assessment 2002: Persistent Organic Pollutants in the Arctic. Arctic Monitoring and Assessment Programme (AMAP), Oslo, Norway; 2004

Anderson ORJ, Philips RA, McDonald RA, Shore RF, McGill RAR, Bearhop S. Influence of trophic position and foraging range on mercury levels within a seabird community. Marine Ecology Progress Series. 2009;375:277-88.

Anderson ORJ, Phillips RA, Shore RF, McGill RAR, McDonald RA, Bearhop S. Element patterns in albatrosses and petrels: influence of trophic position, foraging range, and prey type. Environmental Pollution. 2010;158(1):98-107.

ATSDR. Toxicological Profile for Polychlorinated Biphenyls. Atlanta, GA: Agency for Toxic Substances and Disease Registry; 2000.

Bargagli R. Environmental contamination in Antarctic ecosystems. Science of the Total Environment. 2008;400(1):212-26.

Blévin P, Carravieri A, Jaeger A, Chastel O, Bustamante P, Cherel Y. Wide range of mercury contamination in chicks of Southern Ocean seabirds. PloS One. 2013;8(1):e54508.

Bocher P, Caurant F, Miramand P, Cherel Y, Bustamante P. Influence of the diet on the bioaccumulation of heavy metals in zooplankton-eating petrels at Kerguelen archipelago, Southern Indian Ocean. Polar Biology. 2003;26(12):759-67.

Bond AL, Lavers JL. Trace element concentrations in feathers of Flesh-footed shearwaters (Puffinus carneipes) from across their breeding range. Archives of Environmental Contamination and Toxicology. 2011;61:318-26.

Borgå K, Gabrielsen GW, Skaare JU. Biomagnification of organochlorines along a Barents Sea food chain. Environmental Pollution. 2001;113(2):187-98.

Borgå K, Wolkers H, Skaare JU, Hop H, Muir DC, Gabrielsen GW. Bioaccumulation of PCBs in Arctic seabirds: influence of dietary exposure and congener biotransformation. Environmental Pollution. 2005;134(3):397-409.

Borgå K, Campbell L, Gabrielsen GW, Norstrom RJ, Muir DC, Fisk AT. Regional and species specific bioaccumulation of major and trace elements in Arctic seabirds. Environmental Toxicology and Chemistry. 2006;25(11):2927-36.

Braune BM, Gaskin DE. Mercury levels in Bonaparte's gulls (Larus philadelphia) during autumn molt in the Quoddy Region, New Brunswick Canada. Archives of Environmental Contamination and Toxicology. 1987;16:539-49.

Braune BM, Outridge PM, Fisk AT, Muir DCG, Helm PA, Hobbs K, Hoekstra PF, Kuzyk ZA, Kwan M, Letcher RJ, Lockhart WL, Norstrom RJ, Stern GA, Stirling I. Persistent organic pollutants and mercury in marine biota of the Canadian Arctic: An overview of spatial and temporal trends. Science of the Total Environment. 2005;351-352:456.

Buckman AH, Norstrom RJ, Hobson KA, Karnovsky NJ, Duffe J, Fisk AT. Organochlorine contaminants in seven species of Arctic seabirds from northern Baffin Bay. Environmental Pollution. 2004;128(3):327-38.

Burger J. Metals in avian feathers: bioindicators of environmental pollution. Reviews of Environmental Contamination Toxicology. 1993;5:203-311.

Burger J, Gochfeld M. Risk, mercury levels, and birds: relating adverse laboratory effects to field biomonitoring. Environmental Research. 1997;75(2):160-72.

Burger J, Gochfeld M. Marine birds as sentinels of environmental pollution. Ecohealth. 2004;1:263-74.

Bustamante, P., Carravieri, A., Goutte, A., Barbraud, C., Delord, K., Chastel, O., Weimerskirch, H., Cherel, Y., 2016. High feather mercury concentrations in the wandering albatross are related to sex, breeding status and trophic ecology with no demographic consequences. Environ. Res. 144 (Part A), 1-10.

Bustnes JO, Bakken V, Erikstad KE, Mehlum F, Skaare JU. Patterns of incubation and nest-site attentiveness in relation to organochlorine (PCB) contamination in glaucous gulls. Journal of Applied Ecology. 2001;38:791-801.

Bustnes JO, Folstad I, Erikstad KE, Fjeld M, Miland Ø, Skaare JU. Blood concentration of organochlorine pollutants and wing feather asymmetry in glaucous gulls. Functional Ecology. 2002;16(5):617-22.

Bustnes JO, Erikstad KE, Skaare JU, Bakken V, Mehlum F. Ecological effects of organochlorine pollutants in the Arctic: a study of the Glaucous gull. Ecological Applications. 2003;13(2):504-15.

Bustnes JO, Tveraa T, Varpe $\varnothing$, Henden JA, Skaare JU. Reproductive performance and organochlorine pollutants in an Antarctic marine top predator: the south polar skua. Environment International. 2007;33(7):911-8

Carravieri A, Bustamante P, Churlaud C, Cherel Y. Penguins as bioindicators of mercury contamination in the Southern Ocean: Birds from the Kerguelen Islands as a case study. Science of the Total Environment. 2013;454:141-8.

Carravieri A, Bustamante P, Churlaud C, Fromant A, Cherel Y. Moulting patterns drive within-individual variations of stable 
isotopes and mercury in seabird body feathers: implication for monitoring of the marine environment. Marine Biology. 2014a 161:963-968.

Carravieri A, Bustamante P, Tartu S, Meillère A, Labadie P, Budzinski H, Peluhet L, Barbraud C, Weimerskirch H, Chastel $\mathrm{O}$, Cherel Y. Wandering albatrosses document latitudinal variations in the transfer of persistent organic pollutants and mercury to Southern Ocean predators. Environmental Science and Technology. 2014b;48:14746-55.

Carravieri A, Cherel Y, Blévin P, Brault-Favrou M, Chastel O, Bustamante P. Mercury exposure in a large subantarctic avian community. Environmental Pollution. 2014c;190:51-7.

Cherel Y, Bocher P, De Broyer C, Hobson KA. Food and feeding ecology of the sympatric thin-billed Pachyptila belcheri and Antarctic P. desolata prions at Iles Kerguelen, Southern Indian Ocean. Marine Ecology Progress Series. 2002;228:263-81

Colabuono FI, Taniguchi S, Montone RC. Organochlorine contaminants in albatrosses and petrels during migration in South Atlantic Ocean. Chemosphere. 2012;86(7):701-8.

Connan M, Cherel Y, Mayzaud P. Lipids from stomach oil of procellariiform seabirds document the importance of myctophid fish in the Southern Ocean. Limnolgy and Oceanography. 2007;52:2445-2455.

Corsolini S, Kannan K, Imagawa T, Focardi S, Giesy JP. Polychloronaphthalenes and other dioxin-like compounds in Arctic and Antarctic marine food webs. Environmental Science and Technology. 2002;36(16):3490-6.

Corsolini S, Borghesi N, Ademollo N, Focardi S. Chlorinated biphenyls and pesticides in migrating and resident seabirds from East and West Antarctica. Environment International. 2011;37(8):1329-35.

Court, G.S., Davis, L.S., Focardi, S., Bargargli, R., Fossi, C., Leonzio, C., Marili, L., 1997. Chlorinated hydrocarbons in the tissues of south polar skuas (Catharacta maccormicki) and Adélie penguins (Pygoscelis adeliea) from Ross Sea, Antarctica. Environ. Pollut. 97 (3), 295-301.

Crawley MJ, The R. Book. John Wiley \& Sons, Ltd: Chichester, UK; 2007.

Debacker V, Jauniaux T, Coignoul F, Bouquegneau JM. Heavy metals contamination and body condition of wintering Guillemots (Uria aalge) at the Belgian coast from 1993 to 1998. Environmental Research. 2000;84:310-7.

Dietz R, Outridge PM, Hobson KA. Anthropogenic contributions to mercury levels in present-day Arctic animals-A review. Science of the Total Environment. 2009;407:6120-6131.

Eagles-Smith CA, Ackerman JT, Adelsbach TL, Takekawa JY, Miles AK, Keister RA. Mercury correlations among six tissues for four waterbird species breeding in San Francisco Bay, California, USA. Environmental Toxicology and Chemistry. 2008;27(10):2136-53.

Elliott JE, Scheuhammer AM. Heavy metal and metallothionein concentrations in seabirds from the Pacific coast of Canada. Marine Pollution Bulletin. 1997;34(10):794-801.

Fängström B, Athanasiadou M, Athanassiadis I, Bignert A, Grandjean P, Weihe P, Bergman Å. Polybrominated diphenyl ethers and traditional organochlorine pollutants in fulmars (Fulmarus glacialis) from the Faroe Islands. Chemosphere. 2005;60:836-43.

Finkelstein M, Keitt BS, Croll DA, Tershy B, Jarman WM, Rodriguez-Pastor S, Anderson DJ, Sievert PR, Smith DR. Albatross species demonstrate regional differences in North Pacific marine contamination. Ecological Applications. 2006;16:678-86.

Fisk AT, Hobson KA, Norstrom RJ. Influence of Chemical and Biological Factors on Trophic Transfer of Persistent Organic Pollutants in the Northwater Polynya Marine Food Web. Environmental Science and Technology. 2001;35:732-8.

Fitzgerald WF, Lamborg CH, Hammerschmidt CR. Marine biogeochemical cycling of mercury. Chemical Reviews. 2007;107:641-62.

Fridolfsson AK, Ellegren H. A simple and universal method for molecular sexing of non-ratite birds. Journal of Avian Biology. 1999;116-21.

Furness RW. Birds as monitors of pollutants. In Birds as monitors of environmental change, pp. 86-143. Ed. By R. W. Furness and J. J. D. Greenwood pp 356, Chapman and Hall, London, 1993.

Furness RW, Camphuysen KC. Seabirds as monitors of the marine environment. ICES Journal of Marine Science. 1997;54(4):726-37.

Galbán-Malagón, C.J., Del Vento, S., Cabrerizo, A., Dachs, J., 2013. Factors affecting the atmospheric occurrence and deposition of polychlorinated biphenyls in the Southern Ocean. Atmospheric Chemistry and Physics 13, 1202912041.

García-Fernández AJ, Espín S, Martínez-López E. Feathers as a biomonitoring tool of polyhalogenated compounds: a review. Environmental Science and Technology. 2013;47:3028-43.

Goerke H, Weber K, Bornemann H, Ramdohr S, Plötz J. Increasing levels and biomagnification of persistent organic pollutants (POPs) in Antarctic biota. Marine Pollution Bulletin. 2004;48(3):295-302. 
González-Solís J, Sanpera C, Ruiz X. Metals and selenium as bioindicators of geographic and trophic segregation in giant petrels Macronectes spp. Marine Ecology Progress Series. 2002;244:257-64.

Guruge KS, Tanaka H, Tanabe S. Concentration and toxic potential of polychlorinated biphenyl congeners in migratory oceanic birds from the North Pacific and the Southern Ocean. Marine Environmental Research. 2001a;52(3):27188.

Guruge KS, Watanabe M, Tanaka H, Tanabe S. Accumulation status of persistent organochlorines in albatrosses from the North Pacific and the Southern Ocean. Environmental Pollution. 2001b;114(3):389-98.

Hall P. The bootstrap and edgewort expannon. -Springer-Verlag, Berlin; 1992.

Henriksen EO, Gabrielsen GW, Skaare JU. Validation of the use of blood samples to assess tissue concentrations of organochlorines in glaucous gulls, Larus hyperboreus. Chemosphere. 1998;37(13):2627-43.

Henriksen EO, Gabrielsen GW, Trudeau S, Wolkers J, Sagerup K, Skaare JU. Organochlorines and possible biochemical effects in glaucous gulls (Larus hyperboreus) from Bjørnøya, the Barents Sea. Archives of Environmental Contamination and Toxicology. 2000;38(2):234-43.

Hindell MA, Brothers N, Gales R. Mercury and cadmium concentrations in the tissues of three species of southern albatrosses. Polar Biology. 1999;22(2):102-8.

Hirai H, Takada H, Ogata Y, Yamashita R, Mizukawa K, Saha M, Kwan C, Moore C, Gray H, Laursen D, Zettler ER, Farrington JW, Reddy CM, Peacock EE, Ward MW. Organic micropollutants in marine plastics debris from the open ocean and remote and urban beaches. Marine Pollution Bulletin. 2001;62;1683-92.

Ikemoto T, Kunito T, Hanaka H, Baba N, Miyazaki N, Tanabe S. Detoxification mechanisms of heavy metals in marine mammals and seabirds: interaction of selenium with mercury, silver, copper, zinc and cadmium in liver. Archives of Environmental Contamination and Toxicology. 2004;47:402-13.

Ivar do Sul JA, Barnes DK, Costa MF, Convey P, Costa ES, Campos LS. Plastics in the Antarctic environment: Are we looking only at the tip of the iceberg? Oecologia Australis. 2011;15:150-70.

Jenssen BM, Sørmo EG, Baek K, Bytingsvik J, Gaustad H, Ruus A, Skaare JU. Brominated flame retardants in North-East Atlantic marine ecosystems. Environmental Health Perspectives. 2007;115(1):35-41.

Jerez S, Motas M, Benzal J, Diaz J, Barbosa A. Monitoring trace elements in Antarctic penguin chicks from South Shetland Islands, Antarctica. Marine Pollution Bulletin. 2013;69(1-2):67-75.

Kim EY, Goto R, Tanabe S, Tanaka H, Tatsukawa R. Distribution of 14 trace elements in tissues and organs of oceanic seabirds. Archives of Environmental Contamination and Toxicology. 1998;35:638-45.

Kojadinovic J, Bustamante P, Churlaud C, Cosson RP, Le Corre M. Mercury in seabird feathers: Insight on dietary habits and evidence for exposure levels in the western Indian Ocean. Science of the Total Environment. 2007a;384:194-204.

Kojadinovic J, Cosson RP, Le Corre M, Bustamante P. Trace elements in three marine birds breeding on Reunion Island (Western Indian Ocean). Part 2: factors influencing their detoxification. Archives of Environmental Contamination and Toxicology 2007b;52:431-40.

Labadie P, Alliot F, Bourges C, Desportes A, Chevreuil M. Determination of polybrominated diphenyl ethers in fish tissues by matrix solid-phase dispersion and gas chromatography coupled to triple quadrupole mass spectrometry: Case study on European eel (Anguilla anguilla) from Mediterranean coastal lagoons. Analytica Chimica Acta. 2010;675(2):97-105.

Lewis SA, Furness RW. Mercury accumulation and excretion in laboratory reared black-headed gull Larus ridibundus chicks. Archives of Environmental Contamination and Toxicology. 1991;21(2):316-20.

Lock JW, Thompson DR, Furness RW, Bartle JA. Metal concentrations in seabirds of the New Zealand region. Environmental Pollution. 1992;75(3):289-300.

Lucia M, André JM, Gonzalez P, Baudrimont M, Gontier K, Maury-Brachet R, et al. Impact of cadmium on aquatic bird Cairina moschata. Biometals. 2009;22:843-53.

Lucia M, Bocher P, Cosson RP, Churlaud C, Robin F, Bustamante P. Insight on trace element detoxification in the Blacktailed Godwit (Limosa limosa) through genetic, enzymatic and metallothionein analyses. Science of the Total Environment. 2012;423:73-83.

Maervoet J, Chu SG, Covaci A, Voorspoels S, Schepens P. Accumulation and tissue distribution of selected polychlorinated biphenyl congeners in chickens. Chemosphere. 2004;57(1):61-6.

Malcolm HM, Osborn D, Wright J, Wienburg CL, Sparks TH. Polychlorinated biphenyl (PCB) congener concentrations in seabirds found dead in mortality incidents around the British coast. Archives of Environmental Contamination and Toxicology. 2003;45(1):136-47.

Malinga M, Szefer P, Gabrielsen GW. Age, sex and spatial dependent variations in heavy metals levels in the Glaucous Gull (Larus hyperboreus) from the Bjørnøya and Jan Mayen, Arctic. Environmental Monitoring and Assessment. 
2010;169:407-16

Mallory ML, Braune BM, Wayland M, Gilchrist HG, Dickson DL. Contaminants in common eiders (Somateria mollissima) of the Canadian Arctic. Environmental Reviews. 2004;12(4):197-218.

Marchant S, Higgins PJ. Handbook of Australian, New Zealand and Antarctic Birds, vol 1. Oxford University Press, Melbourne; 1990.

Mendes P, Eira C, Torres J, Soares A, Melo P, Vingada J. Toxic element concentration in the Atlantic gannet Morus bassanus (Pelecaniformes, Sulidae) in Portugal. Archives of Environmental Contamination and Toxicology. 2008;55(3):503-9.

Métian M, Bustamante P, Hédouin L, Warnau M. Accumulation of nine metals and one metalloid in the tropical scallop Comptopallium radula from coral reefs in New Caledonia. Environmental Pollution. 2008;152(3):543-52.

Monteiro LR, Furness RW. Seabirds as monitors of mercury in the marine environment. Water, Air, and Soil Pollution. 1995;80(1-4):851-70.

Mora MA, Auman HJ, Ludwig JP, Giesy JP, Verbrugge DA, Ludwig ME. Polychlorinated biphenyls and chlorinated insecticides in plasma of Caspian terns: relationships with age, productivity, and colony site tenacity in the Great Lakes. Archives of Environmental Contamination and Toxicology. 1993;24(3):320-31.

Morel FMM, Kraepiel AML, Amyot M. The chemical cycle and bioaccumulation of mercury. Annual Review of Ecology and Systematics. 1998;29:543-66.

Müller A, Björklund E, von Holst C. On-line clean-up of pressurized liquid extracts for the determination of polychlorinated biphenyls in feeding stuffs and food matrices using gas chromatography-mass spectrometry. Journal of Chromatography A. 2001;925(1):197-205.

Nam DH, Anan Y, Ikemoto T, Okabe Y, Kim EY, Subramanian AK, Kazutoshi S, Tanabe S. Specific accumulation of 20 trace elements in great cormorants (Phalacrocorax carbo) from Japan. Environmental Pollution. 2005;134:503-14.

Norstrom RJ. Understanding bioaccumulation of POPs in food webs. Environmental Science and Pollution Research. 2002;9:300-3.

Quillfeldt P, Cherel Y, Delord K, Weimerskirch H. Cool, cold, or colder? Spatial segregation of prions and blue petrels is explained by differences in preferred sea surface temperatures. Biology Letters. 2015;11:20141090.

R Core Team. R: a language and environment for statistical computing. Vienna, Austria: R Foundation for Statistical Computing. ISBN 3-900051-07-0; 2012. URL http://www.R-project.org/.

Ryan PG, Moore CJ, van Franeker JA, Moloney CL. Monitoring the abundance of plastic debris in the marine environment. Philosophical Transactions of the Royal Society B. 2009;364;1999-2012.

Sagerup K, Helgason LB, Polder A, Strøm H, Josefsen TD, Skare JU, Gabrielsen GW. Persistent organic pollutants and mercury in dead and dying glaucous gulls (Larus hyperboreus) at Bjørnøya (Svalbard). Science of the Total Environment. 2009;407:6009-16.

Sanchez-Hernandez J. Trace element contamination in Antarctic ecosystems. Reviews of Environmental Contamination and Toxicology. 2000;166:83-127.

Scheuhammer AM. The chronic toxicity of aluminium, cadmium, mercury, and lead in birds: a review. Environmental Pollution. 1987;46(4):263-95.

Seco Pon JP, Beltrame O, Marcovecchio J, Favero M, Gandini P. Trace metals (Cd, $\mathrm{Cr}, \mathrm{Cu}, \mathrm{Fe}, \mathrm{Ni}, \mathrm{Pb}$, and $\mathrm{Zn}$ ) in feathers of Black-browed Albatross Thalassarche melanophrys attending the Patagonian Shelf. Marine Environmental Research. 2011;72(1):40-5.

Stewart FM, Thompson DR, Furness RW, Harrison N. Seasonal variation in heavy metal levels in tissues of common guillemots Uria aalge from northwest Scotland. Archives of Environmental Contamination and Toxicology. 1994;27:168-75.

Tanabe S, Watanabe M, Minh TB, Kunisue T, Nakanishi S, Ono H, Tanaka H. PCDDs, PCDFs, and coplanar PCBs in Albatross from the North Pacific and Southern Oceans: levels, patterns, and toxicological implications. Environmental Science and Technology. 2004;38:403-13.

Tanaka, K., Takada, H., Yamashita, R., Mizukawa, K., Fukuwaka, M., Watanuki, Y., 2013. Accumulation of plastic-derived chemicals in tissues of seabirds ingesting marine plastics. Marine Pollution Bulletin 69, 219-22.

Tao L, Kannan K, Kajiwara N, Costa MM, Fillmann G, Takahashi S, Tanabe S. Perfluorooctanesulfonate and Related Fluorochemicals in Albatrosses, Elephant Seals, Penguins, and Polar Skuas from the Southern Ocean. Environmental Science and Technology. 2006;40:7642-8.

Tapie N, Budzinski H, Le Ménach K. Fast and efficient extraction methods for the analysis of polychlorinated biphenyls and polybrominated diphenyl ethers in biological matrices. Analytical and Bioanalytical Chemistry. 2008;391(6):216977. 
Tapie N, Le Menach K, Pasquaud S, Elie P, Devier MH, Budzinski H. PBDE and PCB contamination of eels from the Gironde estuary: From glass eels to silver eels. Chemosphere. 2011;83:175-85.

Van den Brink NW. Directed transport of the volatile organochlorine pollutants to polar regions: the effect on the contamination pattern of Antarctic seabirds. Science of the Total Environment. 1997;198:43-50.

Verreault J, Gabrielsen GW, Bustnes JO. The Svalbard glaucous gull as bioindicator species in the European Arctic: Insight from 35 years of contaminants research. Reviews of Environmental Contamination and Toxicology. 2010;205:77116.

Vorkamp K, Christensen JH, Glasius M, Riget F. Persistent halogenated compounds in black guillemots (Cepphus grylle) from Greenland-levels, compound patterns and spatial trends. Marine Pollution Bulletin. 2004;48:111-121.

Walker CH, Sibly RM, Hopkin SP, Peakall DB. Principles of Ecotoxicology, Fourth Edition, CRC Press, 2012.

Walsh PM. The use of seabirds as monitors of heavy metals in the marine environment. In: Furness RW, Rainbow PS (eds) Heavy metals in the marine environment. CRC, New York, , pp183-204; 1990.

Weimerskirch H, Zotier R, Jouventin P. The avifauna of the Kerguelen Islands. Emu. 1989;89(1):15-29.

Weimerskirch H, Fradet G, Cherel Y. Natural and experimental changes in chick provisioning in a long-lived seabird, the Antarctic prion. J ournal of Avian Biology. 1999; 30:165-174. 
Table 1. Trace element concentrations (mean $\pm \mathrm{SD}, \mu \mathrm{g} \mathrm{g}{ }^{-1} \mathrm{dw}$; number of samples above the limit of detection (LoD) are given in brackets) in blood, liver, kidney, muscle and feathers of 10 Antarctic prions from Kerguelen Islands.

\begin{tabular}{|c|c|c|c|c|c|c|c|c|c|c|c|c|c|c|}
\hline & $\mathrm{Ag}$ & As & $\mathrm{Cd}$ & Co & $\mathrm{Cr}$ & $\mathrm{Cu}$ & $\mathrm{Fe}$ & $\mathrm{Hg}$ & $\mathrm{Mn}$ & $\mathrm{Ni}$ & $\mathrm{Pb}$ & $\mathrm{Se}$ & V & $\mathrm{Zn}$ \\
\hline Blood & $<\mathrm{LoD}$ & $\begin{array}{l}0.55 \pm 0.20 \\
\quad(9)\end{array}$ & $\begin{array}{l}1.2 \pm 0.4 \\
(10)\end{array}$ & $<\mathrm{LoD}$ & $\begin{array}{c}0.10(<\text { LoD- } 0.10) \\
(2)\end{array}$ & $\begin{array}{c}2.5 \pm 1.9 \\
(10)\end{array}$ & $\begin{array}{c}1620 \pm 397 \\
(10)\end{array}$ & $\begin{array}{l}0.67 \pm 0.11 \\
\quad(10)\end{array}$ & $\begin{array}{l}0.65 \pm 0.20 \\
\quad(10)\end{array}$ & $<\mathrm{LoD}$ & $<\mathrm{LoD}$ & $\begin{array}{c}102 \pm 33 \\
(10)\end{array}$ & $<\mathrm{LoD}$ & $\begin{array}{l}32 \pm 10 \\
(10)\end{array}$ \\
\hline Liver & $<\mathrm{LoD}$ & $\begin{array}{l}2.7 \pm 0.8 \\
(10)\end{array}$ & $\begin{array}{c}36 \pm 8 \\
(10)\end{array}$ & $\begin{array}{c}0.17 \pm 0.05 \\
(10)\end{array}$ & $\begin{array}{l}2.7 \pm 1.3 \\
\quad(10)\end{array}$ & $\begin{array}{c}23 \pm 6 \\
(10)\end{array}$ & $\begin{array}{c}2465 \pm 863 \\
(10)\end{array}$ & $\begin{array}{c}1.8 \pm 0.3 \\
(10)\end{array}$ & $\begin{array}{c}16 \pm 4 \\
(10)\end{array}$ & $\begin{array}{c}1.1 \pm 0.6 \\
(10)\end{array}$ & $<\mathrm{LoD}$ & $\begin{array}{l}73 \pm 18 \\
\quad(10)\end{array}$ & $<\mathrm{LoD}$ & $\begin{array}{l}249 \pm 40 \\
\quad(10)\end{array}$ \\
\hline Kidney & $<\mathrm{LoD}$ & $\begin{array}{l}0.78 \pm 0.25 \\
\quad(10)\end{array}$ & $\begin{array}{c}105 \pm 37 \\
(10)\end{array}$ & $\begin{array}{l}0.23 \pm 0.04 \\
\quad(10)\end{array}$ & $\begin{array}{c}3.1 \pm 1.3 \\
\quad(10)\end{array}$ & $\begin{array}{c}15 \pm 3 \\
(10)\end{array}$ & $\begin{array}{c}568 \pm 63 \\
\quad(10)\end{array}$ & $\begin{array}{c}0.88 \pm 0.16 \\
\quad(10)\end{array}$ & $\begin{array}{c}6.9 \pm 1.0 \\
\quad(10)\end{array}$ & $\begin{array}{c}1.6 \pm 0.7 \\
(10)\end{array}$ & $<\mathrm{LoD}$ & $\begin{array}{l}88 \pm 17 \\
(10)\end{array}$ & $<\mathrm{LoD}$ & $\begin{array}{l}147 \pm 18 \\
\quad(10)\end{array}$ \\
\hline Muscle & $<\mathrm{LoD}$ & $\begin{array}{l}0.93 \pm 0.20 \\
\quad(10)\end{array}$ & $\begin{array}{l}2.8 \pm 0.8 \\
(10)\end{array}$ & $\begin{array}{l}0.10 \pm 0.02 \\
\quad(10)\end{array}$ & $\begin{array}{l}2.2 \pm 1.1 \\
\quad(10)\end{array}$ & $\begin{array}{c}37 \pm 6 \\
(10)\end{array}$ & $\begin{array}{l}559 \pm 108 \\
\quad(10)\end{array}$ & $\begin{array}{l}0.28 \pm 0.06 \\
\quad(10)\end{array}$ & $\begin{array}{c}4.0 \pm 0.6 \\
(10)\end{array}$ & $\begin{array}{l}0.83 \pm 0.48 \\
(9)\end{array}$ & $<\mathrm{LoD}$ & $\begin{array}{c}34 \pm 5 \\
(10)\end{array}$ & $<\mathrm{LoD}$ & $\begin{array}{l}92 \pm 15 \\
\quad(10)\end{array}$ \\
\hline Feathers & $<\mathrm{LoD}$ & $\begin{array}{c}0.37(<\text { LoD- } 0.51) \\
(2)\end{array}$ & $\begin{array}{c}0.06 \pm 0.03 \\
\quad(10)\end{array}$ & $<\mathrm{LoD}$ & $\begin{array}{c}0.49 \pm 1.05 \\
(8)\end{array}$ & $\begin{array}{c}6.1 \pm 2.1 \\
\quad(10)\end{array}$ & $\begin{array}{l}12.5 \pm 5.4 \\
\quad(10)\end{array}$ & $\begin{array}{l}2.8 \pm 1.2 \\
(10)\end{array}$ & $\begin{array}{c}1.1 \pm 0.7 \\
(10)\end{array}$ & $\begin{array}{c}0.71(<\text { LoD-1.34) } \\
(4)\end{array}$ & $\begin{array}{c}0.15 \pm 0.09 \\
(10)\end{array}$ & $\begin{array}{c}6.5 \pm 2.5 \\
\quad(10)\end{array}$ & $<\mathrm{LoD}$ & $\begin{array}{c}72 \pm 19 \\
(10)\end{array}$ \\
\hline
\end{tabular}


Table 2. Persistent organic pollutant concentrations (mean $\pm \mathrm{SD}, \mathrm{ng} \mathrm{g}^{-1} \mathrm{dw}$; number of samples above the limit of detection (LoD) are given in brackets) in liver, kidney and muscle of 10 Antarctic prions from Kerguelen Islands.

\begin{tabular}{|c|c|c|c|c|c|c|c|c|}
\hline & CB-50+28 & CB-52 & CB-101 & CB-118 & CB-138 & CB-153 & CB-180 & $\Sigma_{7} \mathrm{PCBs}$ \\
\hline Liver & $1.1(<\mathrm{LoD}-2.5)(5)$ & $2.8(<\mathrm{LoD}-6.2)(5)$ & $2.6(<$ LoD-6.1) $(5)$ & $5.7 \pm 2.0(10)$ & $8.3 \pm 3.5(10)$ & $14 \pm 7(10)$ & $2.5 \pm 1.4(10)$ & $37 \pm 16$ \\
\hline Kidney & $0.24(<$ LoD-1.63) (1) & $<$ LoQ & $0.65(<$ LoD-3.99) (1) & $3.6 \pm 2.4(7)$ & $6.1 \pm 3.4(10)$ & $10 \pm 6(10)$ & $1.7 \pm 1.3(10)$ & $23 \pm 12$ \\
\hline Muscle & $1.5(<$ LoD-7.5) (6) & $3.1(<\mathrm{LoD}-14.8)(5)$ & $2.4(<\mathrm{LoD}-12.4)(5)$ & $5.0 \pm 2.8(10)$ & $6.8 \pm 3.8(10)$ & $12 \pm 7(10)$ & $2.2 \pm 1.3(10)$ & $33 \pm 18$ \\
\hline
\end{tabular}

\begin{tabular}{|c|c|c|c|c|c|c|c|c|c|c|c|c|c|}
\hline & HCB & $\gamma-\mathrm{HCH}$ & Heptachlor & $\begin{array}{c}\text { Cis- } \\
\text { chlordane }\end{array}$ & $\begin{array}{c}\text { Trans- } \\
\text { nonachlor }\end{array}$ & 2,4'-DDE & 4,4'-DDE & 2,4'-DDD & 4,4'-DDD & 2,4'-DDT & 4,4'-DDT & Mirex & $\Sigma_{12} \mathrm{OCPs}$ \\
\hline Liver & $\begin{array}{l}21 \pm 8 \\
(10)\end{array}$ & $\begin{array}{l}0.58 \pm 0.28 \\
\quad(9)\end{array}$ & $<\mathrm{LoD}$ & $\begin{array}{c}1.9 \pm 0.9 \\
(10)\end{array}$ & $\begin{array}{c}1.0 \pm 0.5 \\
(10)\end{array}$ & $\begin{array}{c}0.96 \pm 0.35 \\
\quad(10)\end{array}$ & $\begin{array}{l}50 \pm 51 \\
\quad(10)\end{array}$ & $<\mathrm{LoD}$ & $<\mathrm{LoQ}$ & $<$ LoQ & $<\mathrm{LoQ}$ & $\begin{array}{l}25 \pm 17 \\
(10)\end{array}$ & $103 \pm 68$ \\
\hline Kidney & $\begin{array}{c}16 \pm 6 \\
(10)\end{array}$ & $\begin{array}{c}0.27(<\text { LoD }-0.78) \\
(5)\end{array}$ & $<\mathrm{LoD}$ & $\begin{array}{l}1.0 \pm 0.8 \\
(7)\end{array}$ & $\begin{array}{l}0.56 \pm 0.40 \\
\quad(8)\end{array}$ & $\begin{array}{c}0.43(<\text { LoD-1.07) } \\
(6)\end{array}$ & $\begin{array}{l}32 \pm 41 \\
\quad(10)\end{array}$ & $<\mathrm{LoD}$ & $\begin{array}{c}0.46(<\mathrm{LoD}-2.87) \\
(1)\end{array}$ & $<\mathrm{LoQ}$ & $<\mathrm{LoQ}$ & $\begin{array}{l}23 \pm 22 \\
\quad(10)\end{array}$ & $75 \pm 60$ \\
\hline Muscle & $\begin{array}{c}9.8 \pm 2.3 \\
\quad(10)\end{array}$ & $\begin{array}{c}0.53 \pm 0.58 \\
(9)\end{array}$ & $<\mathrm{LoQ}$ & $\begin{array}{c}1.3 \pm 1.0 \\
(10)\end{array}$ & $\begin{array}{l}0.78 \pm 0.28 \\
\quad(10)\end{array}$ & $\begin{array}{c}0.80 \pm 0.93 \\
(9)\end{array}$ & $\begin{array}{c}46 \pm 53 \\
(10)\end{array}$ & $<\mathrm{LoD}$ & $\begin{array}{l}2.2 \pm 1.4 \\
(8)\end{array}$ & $<\mathrm{LoQ}$ & $\begin{array}{c}0.27 \pm 0.22 \\
(8)\end{array}$ & $\begin{array}{l}22 \pm 11 \\
(10)\end{array}$ & $85 \pm 64$ \\
\hline
\end{tabular}

\begin{tabular}{|c|c|c|c|c|c|c|c|c|c|c|c|c|}
\hline & BDE-17 & BDE-28 & BDE-47 & BDE-49+71 & BDE-66 & BDE-99 & BDE-100 & BDE-153 & BDE-154 & BDE-183 & BDE-209 & $\Sigma_{11}$ PBDEs \\
\hline Liver & $<\mathrm{LoD}$ & $\begin{array}{l}0.22 \pm 0.14 \\
(10)\end{array}$ & $<$ LoQ & $<\mathrm{LoD}$ & $<\mathrm{LoD}$ & $<\mathrm{LoD}$ & $<\mathrm{LoD}$ & $\begin{array}{c}0.31(<\text { LoD }-1.50) \\
(2)\end{array}$ & $\begin{array}{c}0.04(<\text { LoD- } 0.26) \\
(1)\end{array}$ & $\begin{array}{c}0.34 \text { (<LoD-2.33) } \\
\text { (2) }\end{array}$ & $\begin{array}{c}115(<\text { LoD-1023) } \\
\text { (3) }\end{array}$ & $118 \pm 326$ \\
\hline Kidney & $<\mathrm{LoD}$ & $<$ LoQ & $\begin{array}{c}0.06(<\mathrm{LoQ}-0.13) \\
(5)\end{array}$ & $<\mathrm{LoD}$ & $<\mathrm{LoD}$ & $<$ LoQ & $<\mathrm{LoD}$ & $\begin{array}{c}0.13(<\text { LoD- } 0.75) \\
(2)\end{array}$ & $\begin{array}{c}0.33(<\text { LoD- } 0.18) \\
(1)\end{array}$ & $\begin{array}{c}0.20(<\text { LoD }-1.37) \\
(2)\end{array}$ & $\begin{array}{c}36(<\mathrm{LoD}-321) \\
(4)\end{array}$ & $37 \pm 101$ \\
\hline Muscle & $<\mathrm{LoD}$ & $\begin{array}{c}0.23 \pm 0.37 \\
(8)\end{array}$ & $\begin{array}{c}0.03 \pm 0.02 \\
(9)\end{array}$ & $<\mathrm{LoD}$ & $<\mathrm{LoD}$ & $\begin{array}{c}0.02(<\text { LoD-0.04) } \\
(1)\end{array}$ & $<\mathrm{LoD}$ & $\begin{array}{c}0.27 \text { (<LoQ-1.26) } \\
\text { (4) }\end{array}$ & $\begin{array}{c}0.06(<\text { LoD- } 0.30) \\
(2)\end{array}$ & $\begin{array}{l}0.32 \pm 0.62 \\
\quad(7)\end{array}$ & $\begin{array}{c}4.1(<\mathrm{LoD}-25.6) \\
(5)\end{array}$ & $5.8 \pm 10.5$ \\
\hline
\end{tabular}


Fig. 1. $\mathrm{Cd}, \mathrm{Cu}, \mathrm{Hg}$ and Se concentrations $\left(\mu \mathrm{g} \mathrm{g} \mathrm{g}^{-1} \mathrm{dw}\right)$ in blood (B), liver (L), kidney (K), muscle (M) and feathers (F) of Antarctic prions from Kerguelen Islands $(n=10)$.
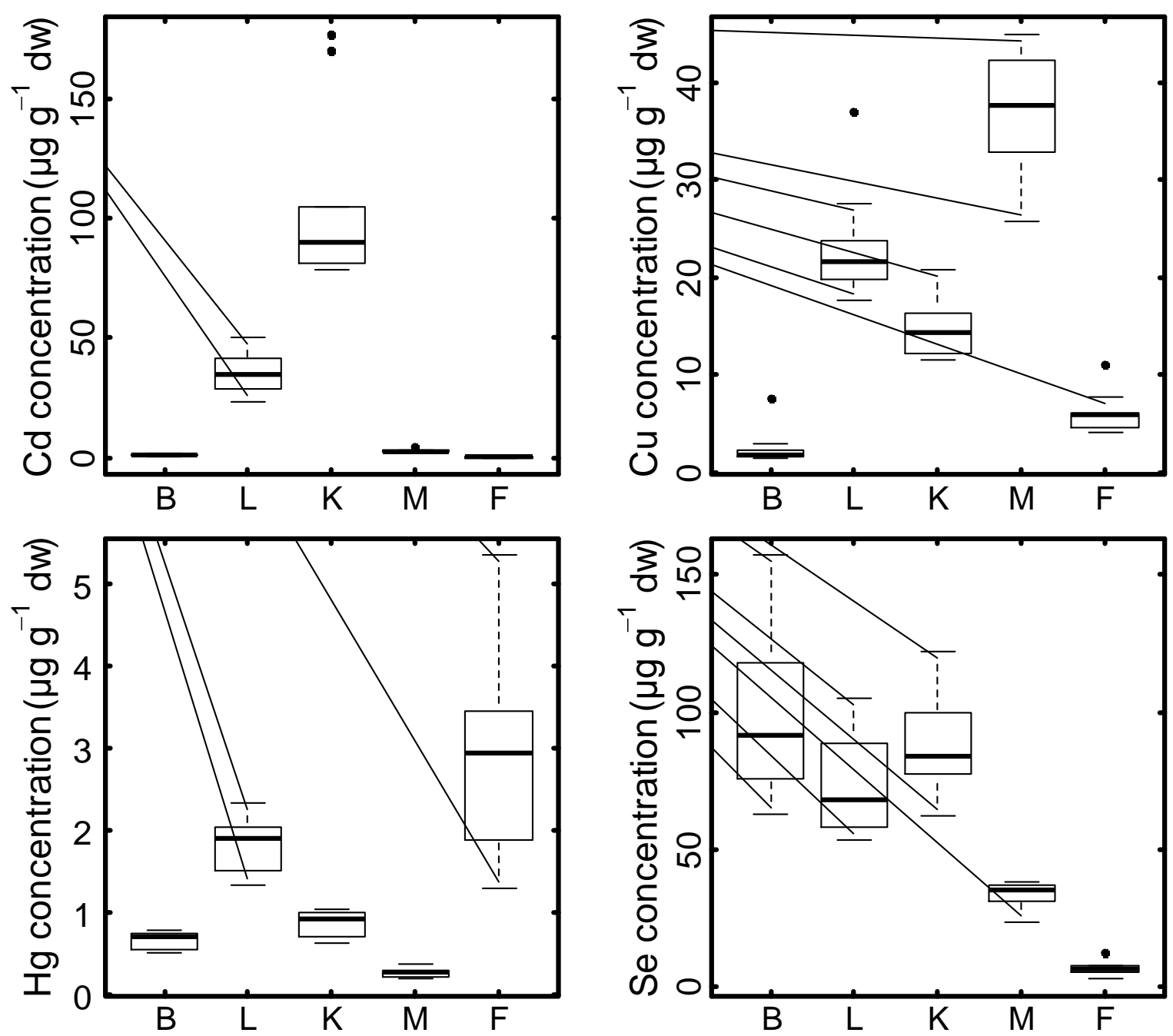
Fig. 2. Relationships between $\mathrm{Hg}$ concentrations $\left(\mu \mathrm{g} \mathrm{g}^{-1} \mathrm{dw}\right.$ ) in liver, kidney, and muscle versus those in blood of Antarctic prions from Kerguelen Islands $(n=10)$.
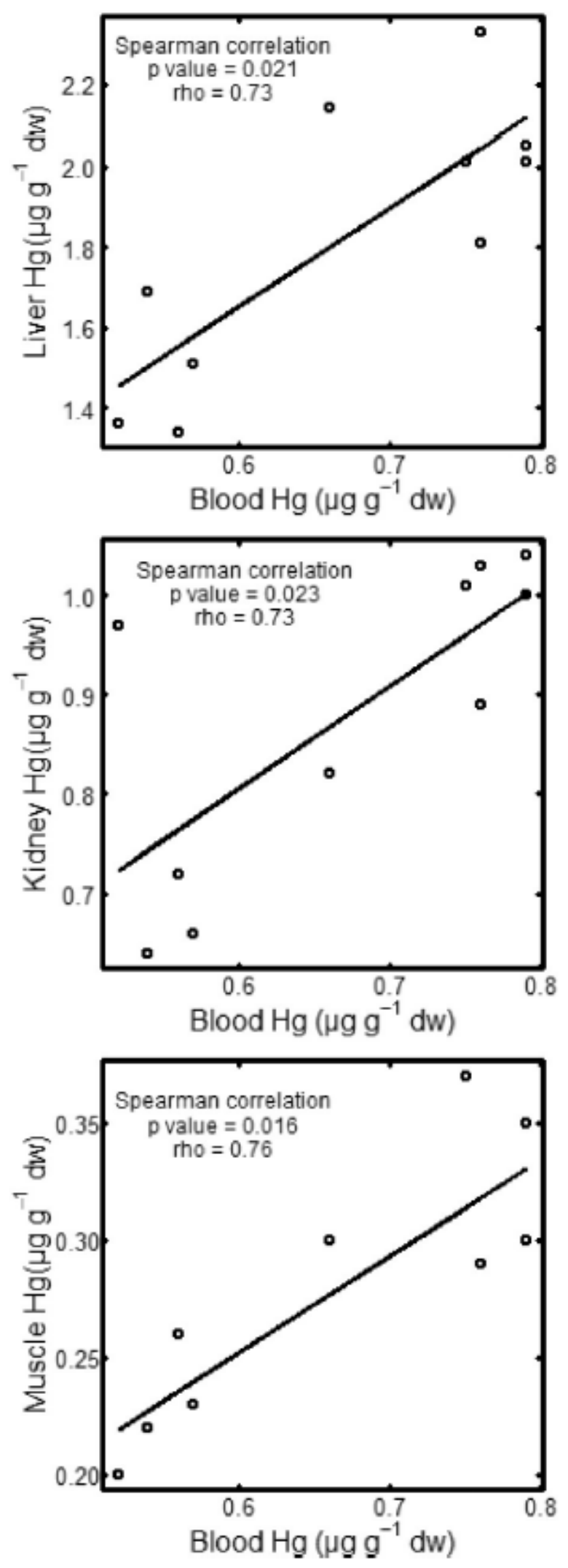
Fig. 3. $\sum_{7} \mathrm{PCB}$ and selected $\mathrm{OCPs}\left(\mathrm{HCB}\right.$, mirex and 4,4'-DDE) concentrations (ng g $\left.{ }^{-1} \mathrm{dw}\right)$ in liver, kidney and muscle of Antarctic prions from Kerguelen Islands $(n=10)$.
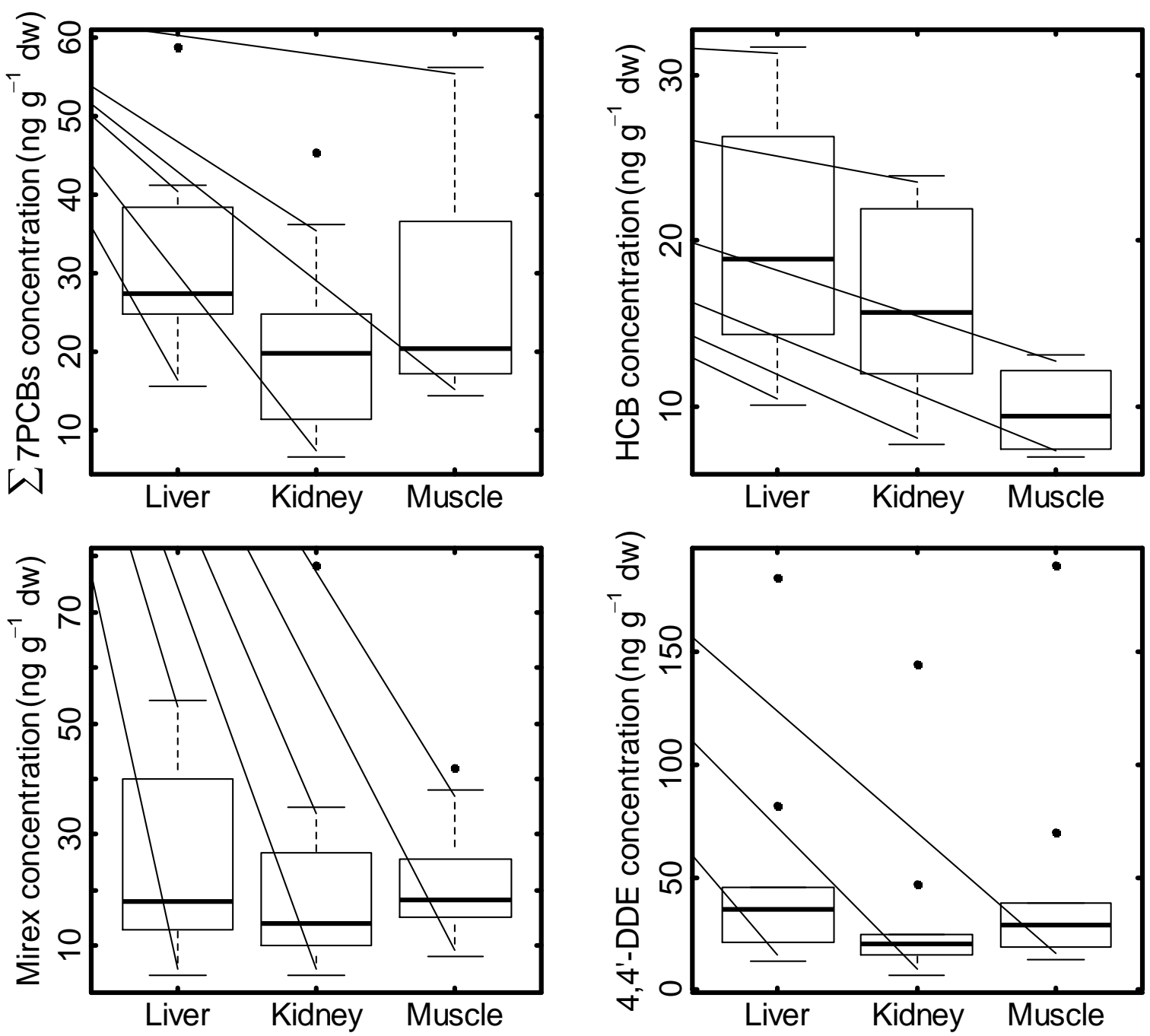
Fig. 4. Relationship between liver and kidney concentrations ( $\mathrm{ng} \mathrm{g}^{-1} \mathrm{dw}$ ) of $\sum_{12} \mathrm{OCPs}$ and CB153 in Antarctic prions from Kerguelen Islands $(n=10)$.
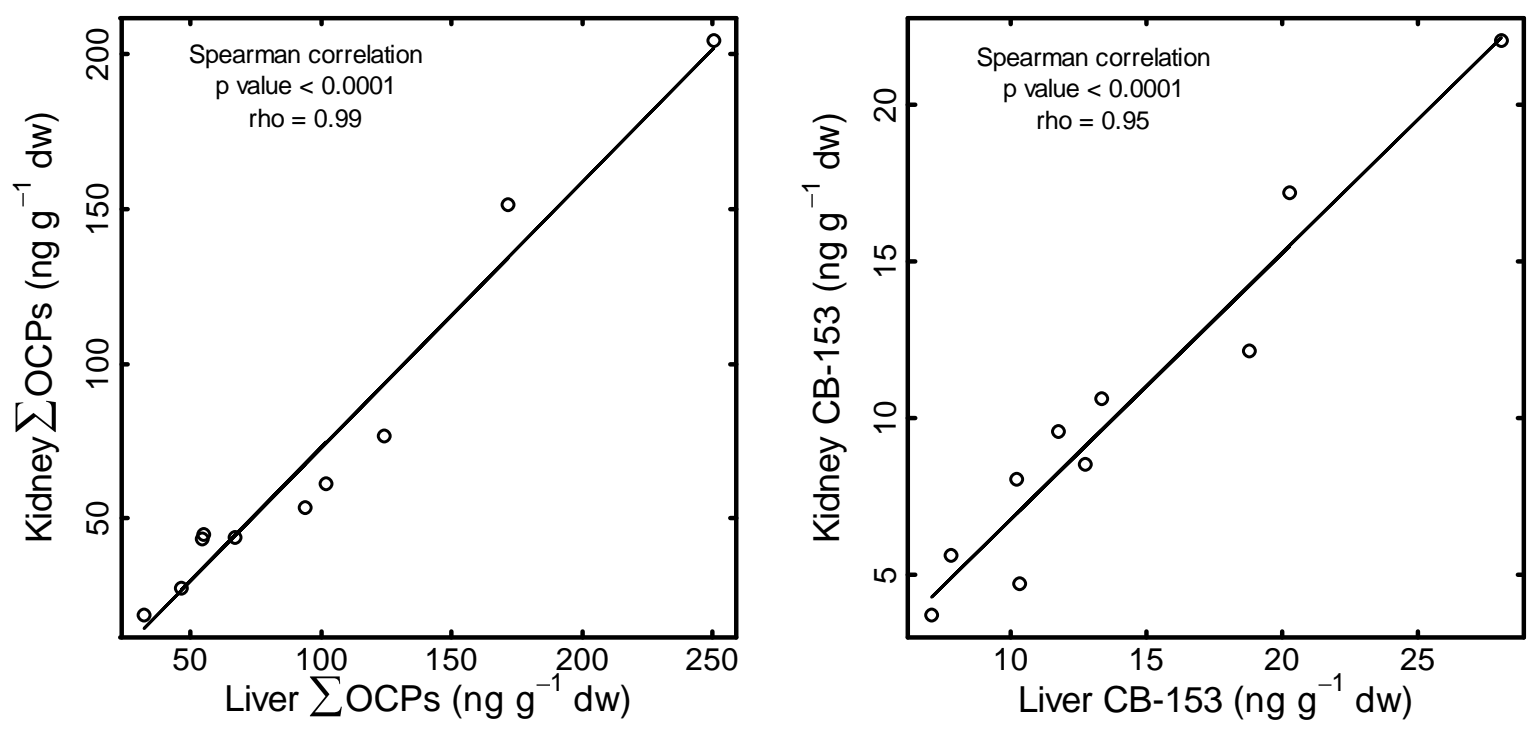
Fig. 5. Relationship between CB-153 and CB-180 concentrations ( $\left.\mathrm{ng} \mathrm{g}^{-1} \mathrm{dw}\right)$ in liver, kidney and muscle of Antarctic prions from Kerguelen Islands $(n=10)$.
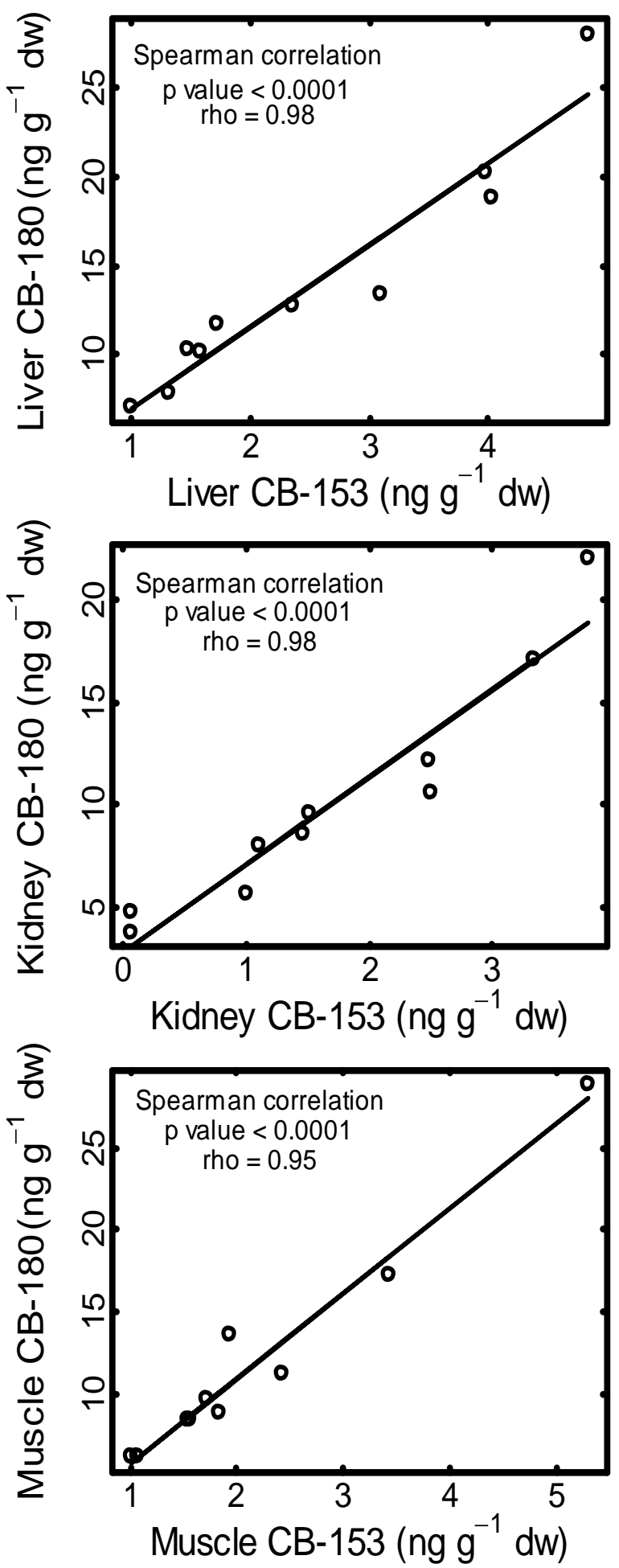
Fig. 6. Stacked bar plot of POPs in liver, kidney and muscle of Antarctic prions from Kerguelen Islands $(\mathrm{n}=10)$. Values correspond to median concentrations. Compounds with a contribution $<0.5 \%$ were not included $(\gamma-\mathrm{HCH}$, heptachlor, 2,4'-DDD, 2,4'-DDT, 4,4'-DDT, and BDEs 28, 47, 99, 153, 154, 183, 206 and 207).

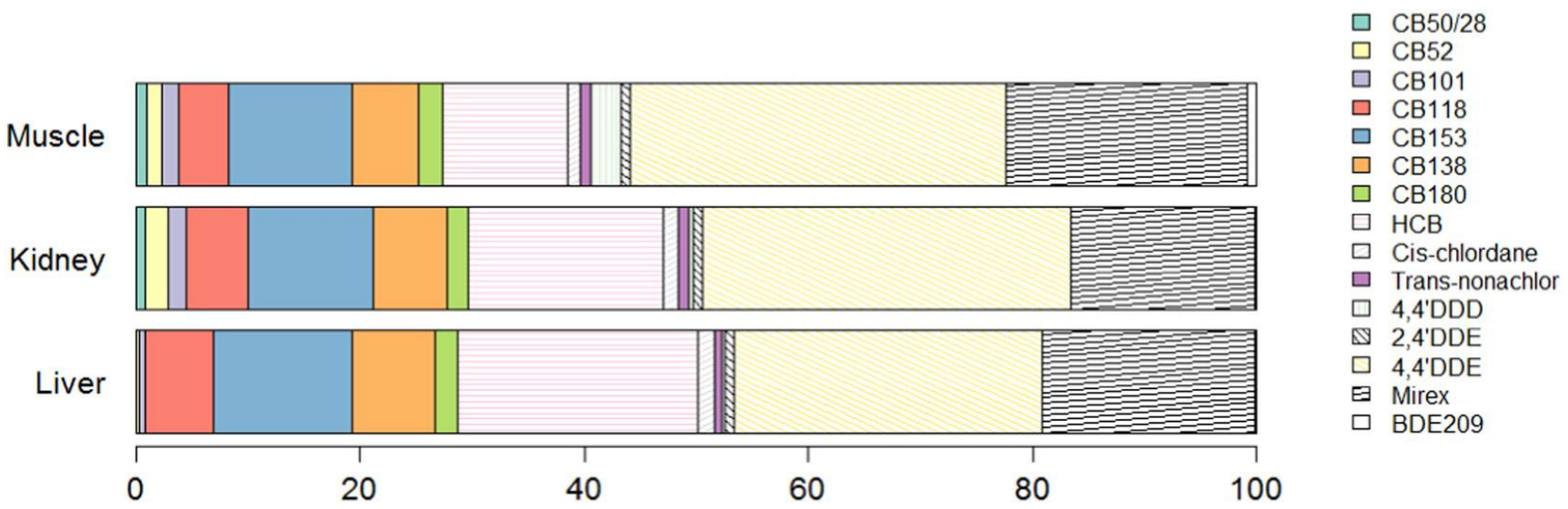

Proportion of POPs concentration in liver, kidney and muscle (\%) 